\title{
Prevalence of Iron Deficiency Anaemia in School and College Going Students of District Shaheed Benazirabad Sindh Province, Pakistan
}

\author{
Niaz Hussain Jamali'1, Hidayatullah Mahesar², Muhammad Aqeel Bhutto ${ }^{3}$ \\ ${ }^{1}$ Department of Community Medicine, Peoples University of Medical and Health Sciences for Women, Nawabshah, Pakistan \\ ${ }^{2}$ Department of Physiology, University of Sindh Jamshoro, Jamshoro, Pakistan \\ ${ }^{3}$ Institute of Biotechnology and Genetic Engineering, University of Sindh, Jamshoro, Pakistan \\ Email:niazhussain858@yahoo.com,hidayat_mahesar@yahoo.com,aqeel_bhutto@hotmail.com
}

How to cite this paper: Jamali, N.H., Mahesar, H. and Bhutto, M.A. (2016) Prevalence of Iron Deficiency Anaemia in School and College Going Students of District Shaheed Benazirabad Sindh Province, Pakistan. Open Journal of Blood Diseases, 6, 67-78. http://dx.doi.org/10.4236/ojbd.2016.64010

Received: October 27, 2016

Accepted: December 17, 2016

Published: December 20, 2016

Copyright $\odot 2016$ by authors and Scientific Research Publishing Inc. This work is licensed under the Creative Commons Attribution International License (CC BY 4.0).

http://creativecommons.org/licenses/by/4.0/

\begin{abstract}
The present study aimed to estimate the occurrence of Iron Deficiency anemia (IDA) in school and college going students (aged $11-18$ years). Anemia is the most public health problem in school age children. It has a wide range of adverse results involving, poor cognitive performance, poor development of infants, preschool and schoolaged children. Anemia also causes the impairment of physical capacity, work performance of adolescents and adults, reduction in immune competence and increased morbidity from infections in all age groups. Our study based on 1686 volunteers was randomly selected from different Government High schools and colleges. A Questionnaire was utilized for data collection. BMI was also calculated by dividing weight in $\mathrm{kg}$ by the square of height in meters. Hemoglobin (Hb), Hematocrite (Hct), Mean Corpuscular volume (MCV), Mean Corpuscular hemoglobin concentration (MCHC), white blood cell (WBC) and red blood cell was examined using Sysmex kx-21N hemoglobin auto analyzer (Hedwin, 2008). The total percentage of anaemic students (43.1\%) and non-anaemic (56.9\%) were observed in district Shaheed Benazirabad. The mean $\mathrm{Hb}$ level of anaemic students $(11.1 \pm 4.94)$ was observed. In males $(12.7 \%)$ and females (30.4\%) anemic was observed. The prevalence of anemia high (16.2\%) was observed in the age of 14 - 16 years. The majority of anemic patients (30.2\%) belonged to low income group. Area wise prevalence, in rural areas $27.8 \%$ and urban areas $15.3 \%$ volunteers anaemic was observed. Taluka wise occurrence of anaemia in taluka Sakrand was (14.6\%), in taluka Kazi Ahmed (15.0\%), in taluka Daur (8.0\%) and in taluka Nawabshah was (5.5\%). Clinically signs and symptoms showed, pale skin $57.7 \%$ and weakness $42.3 \%$ were observed in school children.
\end{abstract}

\section{Keywords}

Iron Deficiency Anaemia (IDA), Haemglobin (Hb), Red Blood Cell (RBC), White 
Blood Cell (WBC), Hematocrit (Hct), Body Mass Index (BMI), School Children, Pale Skin

\section{Introduction}

Anaemia is the most important public health problem in school age children. World Health Organization estimated two billions people suffer from anemia in the world [1]. Besides pregnant women, children (both preschool and school-age) are the most affected group by ID because of the quick growth and the general cognitive development [2]. Anaemia is a multi-factorial health problem in which the risk factors could be nutritional (vitamin B12, folate and iron deficiencies), clinical (infectious diseases such as HIV/AIDS, tuberculosis, malaria, general inflammatory disorders and helminthes infections), socioeconomic factors (educational levels of parents and low household income) and demographic factors (age, gender, and family size) [3] [4]. Anaemia has a wide range of adverse results involving, poor cognitive performance, poor development of infants, preschool and school-aged children, impairment of physical capacity, work performance of adolescents and adults, reduction in immune competence and increased morbidity from infections in all age groups [5]. Severe anemia is a simple state causing important morbidity and mortality in children in Africa [6]. Iron deficiency is the result of an iron balance, i.e., the amount absorbed by the intestine may not be satisfactory to meet body needs. However, if the supply of hemopoietic nutrients is inadequate, the bone marrow is dysfunctional and the levels of hemoglobin will be subnormal and a state of anemia will set in. Iron needs depend on age, sex, race, pregnancy, lactation and altitude, because of the different collaborating factors for the development of anemia in children, information of its prevalence, distribution and etiology are important for gaing exact measures for its stopping and control. In Pakistan, nutritional anemia has been documented to be most common type of malnutrition was present in children. According to the 1977, micronutrient research of Pakistan about $38 \%$ of the population was recognized to be anemia [7]. According to Survey of National Nutrition (1988), 65\% of the Pakistani children aged 7 - 60 months were found to be anemic [8]. It also has effect on child development, mental and psychomotor development [9]. Iron deficiency anemia in Pakistan, 65 percent present in children at the age 7 to 60 years and other studies estimated dissimilar common rates i.e. 70 percent, 78 percent [10]. However, researcher reported that about (750 million) children are affected by Iron Deficiency Anaemia and most commonly in children and women in developed countries [11]. About 700,000 children aged 1 to 2 years are iron deficient and $(240,000)$ had anemia iron deficiency [12]. The anemia $50 \%$ is caused by low iron intake. The major risk factors for low iron intake among young children in developing countries are malnutrition (low intake) and high requirement of iron during child development, due to the multifactorial environment, difficulty of risk factors of anemia and potential interactions among them and a single strategy to curb anemia in devel- 
oping countries may have little success. An integrated strategy for anemia control and prevention is required [13]. Erythrocytes or red blood cells indicate the level of $\mathrm{Hb}$ while erythropoietin controls the release of RBC from bone marrow that produced from interstitial fibroblasts in the kidney. Mean while disturbance in several essential micronutrients supplements can effect on the production of new cells. B2 (riboflavin) [14] and Vitamins B6 (pyridoxine) [15] are essential for production of the globin protein whereas iron has to be integrated into the final $\mathrm{Hb}$ molecule [16]. The environmental factors such as oxygen, high altitude, smoking and physiological factors such as gestation influenced on the $\mathrm{Hb}$ availability within the blood [17].

Haemglobin was used to assess anemia and the information collected was intended to estimate of iron shortage at birth, iron deficiency anemia and make strong intention of the predictive value of hemoglobin in Identifying iron deficiency. NHANES data (1999 to 2000) show that, the proportion of children with iron deficiency remained 2\% $5 \%$ points more than the 2010 National Health Objectives [18].

\section{Aim \& Objective}

1) To estimate the occurrence of Iron Deficiency Anaemia in school children aged 11 - 18 years in the four talukas of District Shaheed Benazirabad (Nawabshah).

2) Observing relationship of Iron Deficiency Anaemia with financial status of volunteers.

\section{Methodology}

\subsection{Study Area}

This cross sectional study was conducted in District Shaheed Benazirabad (Nawabshah) during the period of January 2015 to July 2015, for obtaining data; the whole district was divided into four talukas, Sakrand, Nawabshah, Kazi Ahmed and Daur.

\subsection{Study Plan}

The Present study was planned to examine the proportion of anemia in school and college age children in relationship with Socio-economic status, age, education and dietary intake in Shaheed Benazirabad. The students were selected by visiting of different Government High schools and colleges. Boys and girls students aged 11 to 18 years were enrolled for the study. The questionnaire was designed including education, social class, age, sex, and dietary habits.

The verbal consent for acceptance of participation of parents/guardian of selected subjects in the study was obtained. Apparently normal students of both genders were selected and with no history of bleeding, blood transfusion, inflammation, infection, liver disease, malignancy and any extensive surgery. The participants were selected from rural and urban areas of District Shaheed Benazirabad (Nawabshah).

Age wise distribution of children in three Categories

1) 11 - 13 years,

2) 14 - 16 years, 
3) 17 - 18 years.

\subsection{Anthropometric Measurements}

Anthropometrical and clinical examination was carried on these Students. Various anthropometric measurements used were height weight and BMI.

\subsection{Body Mass Index}

It is calculated by dividing weight in $\mathrm{kg}$ by the square of height in meters. The calculations were compared with standard for classification of the sample.

$$
\mathrm{BMI}=\frac{\text { Weight }(\mathrm{kg})}{\text { Height }(\mathrm{m})^{2}}
$$

Since the height of respondents was recorded in centimeters, for the calculation, BMI heights in centimeter were first converted into height in meters.

\subsection{Classification of Body Mass Index}

\begin{tabular}{ccc}
\hline Based on BMI & Body index Kg/m $\mathrm{m}^{2}$ & Health risk associated \\
\hline Under weight & Below 18.5 & Low \\
Normal range & $18.5-25.0$ & Moderate \\
Over weight & $25.1-29.1$ & High \\
Obesity & 30 above & Very high [19] \\
\hline
\end{tabular}

Monthly income of volunteer's parents was divided into three classes. The persons whose monthly income was less than Rs: 20,000/month (Poor/lower class), Rs: 20,000 27,000 (middle class) and more than Rs: 28,000 (middle upper class).

In present study $3 \mathrm{cc}$ blood samples were taken from each of the volunteers.

A total of 1686 blood samples were collected. For the blood sample collection, the collection site was cleaned with antiseptic liquid to kill germs. The blood was drawn from vein by sterilized syringes. The blood samples were collected and poured into EDTA (ethylene diamine tetra acetic acid) tube. For the duration of the blood collection the designed questionnaire was filled from the each participant.

\subsection{Laboratory Work}

The blood samples were immediately carried to Liaquat University of Medical \& Health Sciences Diagnostic Laboratory Hyderabad. Haemglobin (Hb), Hematocrite (Hct), Mean Corpuscular volume (MCV), Mean Corpuscular Haemglobin concentration (MCHC), white blood cell count (WBC) and red blood cell count and platelets were measured by using Sysmex kx-21N Haemglobin auto analyzer (Hedwin, 2008). The lower limit for the hemoglobin $(\mathrm{Hb})$ level was different according to sex. The cut-off value $12 \mathrm{~g} / \mathrm{dl}$ for female and for boys $12.5 \mathrm{~g} / \mathrm{dl}$ of $\mathrm{Hb}$ were considered diagnostic. 


\section{Data Analysis}

The whole data was entered, checked and analyzed by using SPSS version (20) for required statistical parameters including simple mean, frequency distribution, standard deviation, and interpretation of observed results.

\section{Results}

The total numbers of 1686 volunteers were randomly selected from school and college students ( $11-18$ years) with both sexes (Males $946=56.1 \%$ and Females $740=40.3 \%$ ). The questionnaire were filled with clinically observation for the incidence of anemia at district Shaheed Benazirabad. However, after clinical assessment blood samples were collected for additional examination.

The prevalence of Anaemia in school and college students of District Shaheed Benazirabad population was divided into four clusters, volunteers were selected from (680 = $40.3 \%$ urban $),(1006=59.7 \%$ Rural $),(946=56.1 \%$ Males $)$ and $(740=40.3 \%$ females $)$ from taluka Nawabshah (27.6\%), taluka Sakrand (27.3\%), taluka Daur (18.8\%) and taluka Kazi Ahmed (27.3\%) were observed in the present study. The study sample of volunteers was categorized into two groups, anemic and non anemic (Figure 1).

In District Shaheed Benazirabad (43.1\%) students were anemic. The total anemic students (43.1\%) and non-anemic (56.9\%) were observed. The mean Hb level of anemic students $(11.2 \pm 2.94)$ was observed. The prevalence of anemia in male students (12.7\%) and in female students was (30.4\%) and higher prevalence found in female students as compared male students.

The prevalence of anemia in rural areas (27.8\%) and urban areas was (15.3\%), high prevalence anemia recorded in rural areas. The occurrence of anemia in the students of Taluka Kazi Ahmed was (15.0\%) and (14.6\%) in taluka Sakrand. The prevalence was high in taluka Kazi Ahmed and taluka Sakrand respectively (Figure 1).

Table 1 shows that male volunteers $\mathrm{Hb}$ and $\mathrm{BMI}$ level were $12.73 \pm 1.47,19.63 \pm 1.22$ respectively. It was higher in male compared to female volunteers $11.56 \pm 0.86$, and $17.57 \pm 0.70$ respectively.

Table 1. Relationship of socio-demographic characteristics with hemoglobin level and body mass index $(\mathrm{N}=1686)$.

\begin{tabular}{ccccc}
\hline \multirow{2}{*}{ Variable } & \multicolumn{2}{c}{ Frequency of variable } & Hb gram/dL Mean \pm S.D & BMI Mean \pm S.D \\
\cline { 2 - 3 } & No. & $\%$ & & \\
\hline Males & 946 & 56.1 & $12.73 \pm 1.47$ & $19.63 \pm 1.22$ \\
Female & 740 & 43.9 & $11.56 \pm 0.86$ & $17.57 \pm 0.70$ \\
Urban & 680 & 40.3 & $12.52 \pm 1.65$ & $19.04 \pm 1.33$ \\
Rural & 1006 & 59.7 & $12.01 \pm 1.49$ & $18.51 \pm 1.49$ \\
Sakrand & 460 & 27.3 & $11.97 \pm 1.37$ & $18.50 \pm 1.35$ \\
Daur & 300 & 17.8 & $12.26 \pm 1.51$ & $19.07 \pm 1.51$ \\
Kazi Ahmed & 460 & 27.3 & $11.92 \pm 1.01$ & $18.31 \pm 1.32$ \\
Nawabshah & 466 & 27.6 & $12.71 \pm 1.45$ & $19.15 \pm 1.46$ \\
Total & 1686 & 100 & $12.21 \pm 1.37$ & $18.73 \pm 1.45$ \\
\hline
\end{tabular}


In residential area wise (Rural, Urban), in urban region $\mathrm{Hb}=12.52 \pm 1.65$ and $\mathrm{BMI}=$ $19.04 \pm 1.33$ level were higher found as compared to rural areas.

Taluka wise, in taluka Nawabshah $\mathrm{Hb}=12.71 \pm 1.45$ and $\mathrm{BMI}=19.15 \pm 1.46$ were higher found as compared to Taluka Kazi Ahmed, Daur and Sakrand (Table 1).

Table 2 shows that in 14 - 16 age group $16.2 \%$ volunteers were anemic and it was found higher as compared to other age groups.

Table 3 shows that in 15,000 - 20,000 income group 30.2\% volunteers were anemic, it was found high as compared to other income groups.

Table 4 shows that in males volunteers minimum $\mathrm{Hb}$ level $=10.3 \mathrm{~g} / \mathrm{dl}$, and maximum $\mathrm{Hb}=15.4 \mathrm{~g} / \mathrm{dl}$, which was found higher as compared to females volunteers.

Table 5 shows that in rural areas minimum $\mathrm{Hb}$ level $=9.4 \mathrm{~g} / \mathrm{dl}$, and maximum $\mathrm{Hb}=$ $15.3 \mathrm{~g} / \mathrm{dl}$ was lower found as compared to urban areas.

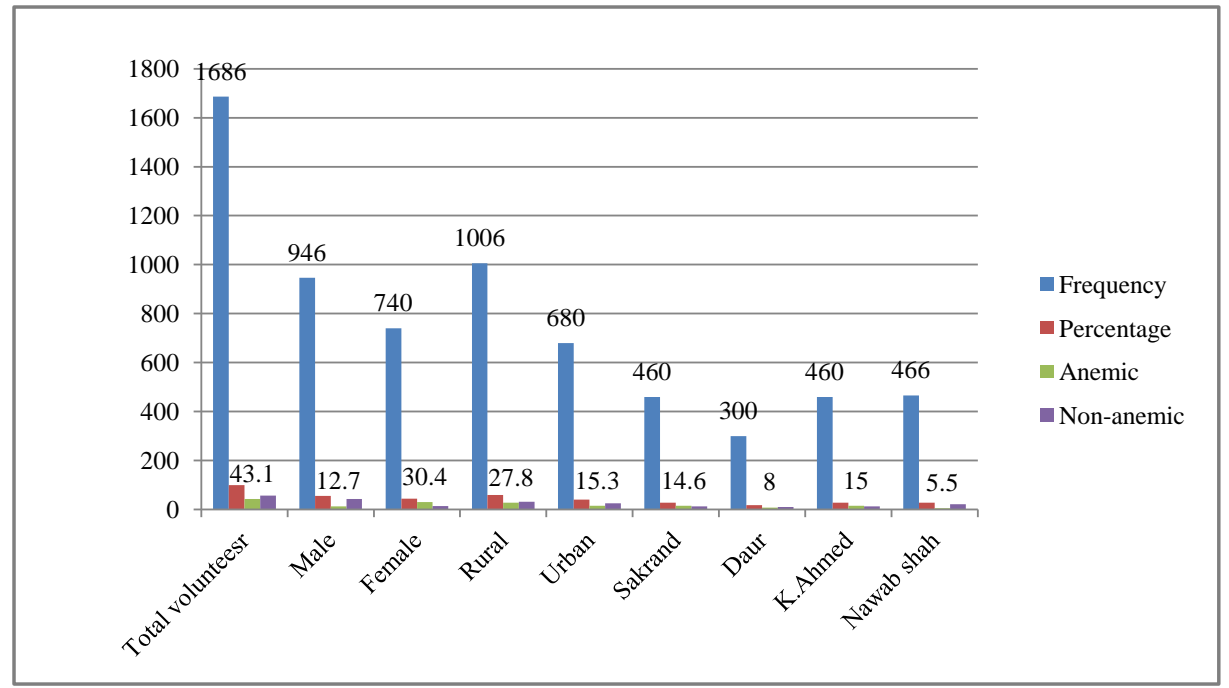

Figure 1. The prevalence of anemia, gender wise, area wise and taluka wise in district Shaheed Benazirabad.

Table 2. Age wise frequency and distributions of volunteers with $\mathrm{Hb}$ less than cut off value.

\begin{tabular}{ccccc}
\hline Variable (Age Groups) & $\mathrm{N}$ & $\%$ & \multicolumn{2}{c}{$\mathrm{Hb}<12.0 \mathrm{gram} / \mathrm{dL}$} \\
\cline { 5 - 6 } & & & $\mathrm{N}$ & $\%$ \\
\hline $11-13$ & 638 & 37.84 & 262 & 16.5 \\
$14-16$ & 648 & 38.43 & 272 & 11.4 \\
$17-18$ & 400 & 23.74 & 192 &
\end{tabular}

Table 3. Income wise frequency and distributions of volunteers with Hb less than cut off value.

\begin{tabular}{ccccc}
\hline Variable (Income Groups) & $\mathrm{N}$ & $\%$ & \multicolumn{2}{c}{$\mathrm{Hb}<12.0 \mathrm{gram} / \mathrm{dL}$} \\
\cline { 4 - 5 } & & & $\mathrm{N}$ & $\%$ \\
\hline $15,000-20,000$ & 928 & 55.1 & 510 & 30.2 \\
$21,000-27,000$ & 518 & 30.7 & 180 & 10.6 \\
$28,000-50,000$ & 240 & 14.2 & 40 & 2.3 \\
\hline
\end{tabular}


Table 6 represents that in 15,000 - 20,000 income group minimum $\mathrm{Hb}$ level $=9.4$ $\mathrm{g} / \mathrm{dl}$ was lowest as compared other income groups.

Table 7 reflects that in 13 - 14 age group maximum $\mathrm{Hb}$ level $=15.4 \mathrm{~g} / \mathrm{dl}$ was high as compared to other age groups.

Table 8 shows that minimum $\mathrm{Hb}$ level $=9.4 \mathrm{~g} / \mathrm{dl}$ are same in all taluka of district Shaheed Benazir Abad.

Table 9 shows that from the total anemic volunteers, pale skin $57.7 \%$ and weakness $42.3 \%$ were observed in school going children.

\section{Discussions}

The present study was organized on 1686 school age students from 11 - 18 years included both sexes (Male and Female) of district Shaheed Benazirabad. Anemia is the most important public health problem affecting more than half of school-age children

Table 4. Gender wise minimum \& maximum $\mathrm{Hb}$ level of volunteers.

\begin{tabular}{ccccc}
\hline \multirow{2}{*}{ Variable } & $\mathrm{N}$ & $\%$ & Minimum & Hb gram/dL \\
\cline { 4 - 5 } & & & 10.3 & Maximum \\
\hline Male & 946 & 56.1 & 9.4 & 15.4 \\
Female & 740 & 43.9 & 9.4 & 15.7 \\
Total & 1686 & 100 & & \\
\hline
\end{tabular}

Table 5. Area wise minimum \& maximum $\mathrm{Hb}$ level of volunteers.

\begin{tabular}{ccccc}
\hline & Variable & \multicolumn{3}{c}{ Hb gram/dL } \\
\hline Area & $\mathrm{N}$ & $\%$ & Minimum & Maximum \\
\hline Urban & 680 & 40.3 & 10.4 & 15.4 \\
Rural & 1006 & 59.7 & 9.4 & 15.3 \\
Total & 1686 & 100 & 9.4 & 15.4 \\
\hline
\end{tabular}

Table 6. Income wise minimum \& maximum $\mathrm{Hb}$ level of volunteers.

\begin{tabular}{ccccc}
\hline Variable (Income Groups) & $\mathrm{N}$ & $\%$ & \multicolumn{2}{c}{ Hb gram/dL } \\
\cline { 5 - 5 } & & & Minimum & Maximum \\
\hline $15,000-20,000$ & 928 & 55.04 & 9.4 & 14.8 \\
$21,000-27,000$ & 518 & 30.72 & 10.6 & 14.8 \\
$28,000-50,000$ & 240 & 14.23 & 10.6 & 15.4 \\
\hline
\end{tabular}

Table 7. Age wise minimum \& maximum $\mathrm{Hb}$ level of volunteers.

\begin{tabular}{cccccc}
\hline Variable (Age Groups) & \multirow{2}{*}{$\%$} & \multicolumn{2}{c}{ Hb gram/dL } \\
\cline { 5 - 6 } & & & & Minimum & Maximum \\
\hline $11-12$ & 638 & 37.84 & 9.5 & 15.3 \\
$13-14$ & 648 & 38.43 & 10.2 & 15.4 \\
$15-16$ & 400 & 23.74 & 9.4 & 14.8 \\
\hline
\end{tabular}


Table 8. Taluka wise minimum \& maximum $\mathrm{Hb}$ level of volunteers.

\begin{tabular}{ccccc}
\hline \multirow{2}{*}{ Variable (Clusters) } & $\mathrm{N}$ & $\%$ & \multicolumn{3}{c}{ Hb gram/dL } \\
\cline { 5 - 6 } & & & Minimum & Maximum \\
\hline Sakrand & 460 & 27.3 & 9.4 & 15.4 \\
Dour & 300 & 17.8 & 9.4 & 15.4 \\
K. Ahmed & 460 & 27.3 & 9.4 & 15.3 \\
N. shah & 466 & 27.6 & 9.4 & 15.4 \\
\hline
\end{tabular}

Table 9. Signs and symptoms (clinically) in anemic students.

\begin{tabular}{ccc}
\hline Signs and symptoms & Anemic & Percentage \\
\hline Pale skin & 443 & 57.7 \\
Weakness & 324 & 42.3 \\
Total & 767 & 100 \\
\hline
\end{tabular}

in growing countries. Anemia in the school age children has been conclusively observed to delay psychomotor development, poor cognitive performance, and impaired immunity and reduce working capacity. The present study estimated iron deficiency anemia in district Shaheed Benazirabad, Sindh Pakistan. The occurrence of anemia was (43.1\%) including both sexes in the age of $11-18$ years in District Shaheed Benazirabad. (Figure 1) The prevalence of anemia in this age was high due to the children require nutritional diet for rapid growth. The prevalence of anemia in Southeast Asia I children was (49\%), in African children was (60\%), in southeast Asia II children was (66\%), in Latin American children was (46\%), in Eastern Mediterranean children was (63\%) and North America children was (7\%) [20]. National Health survey for Pakistan (NHSP) in 1990-1994 proved that the nutritional anemia was presence in children under age of 05 years was (62.9\%). The occurrence of anemia (51.5\%) was among urban school students of Punjab [21].

In the year 1975 to 76 Survey of Nutrition in rural areas of Bangladesh about 70 percent of Bangladeshi peoples suffer from anemia with a mean Haemglobin value of (9.7 $\mathrm{gm} / \mathrm{dl})$. Average Haemglobin level in children ( 0 - 4 years) of neighboring Thailand is $(11.2 \mathrm{gm} / \mathrm{dl})$ which is considerably higher than the values found in past studies. Bhatia et al. (1990) reported that, 74 percent of the males and 75 percent of the school females between 5 to 14 years of age were anemic. Occurrence of anemia was also surveyed in Bangladesh urban and rural Chittagong Hill Tracts [22]. The current study shows that occurrence of anemia were higher in female students (30.4\%) as compared to boys students (12.7\%) in district Shaheed Benazirabad (Figure 1). Verma, M., et al., reported that the occurrence of anemia was increased in girls $51.1 \%$ amongst the urban school students of Punjab than boys except 05 years and 10 - 12 years age. In South India district Bangalore the occurrence of anemia in females (15.3\%) were higher as compared to males (12.0\%). The occurrence of anemia was low in Bangalore because of school based involvement program that have been conducted 2003 [23]. The scenario on the iron status of adolescent girls in the has conducted study was also not satisfactory eva- 
luated the iron status of 199 it seems that healthy male and female adolescents aged 12 to 19 years living in a fishing society in Sabah, Malaysia. The mean hemoglobin value for the females was $(12.4 \pm 1.6 \mathrm{~g} / \mathrm{dl})$ with $(28.6)$ percent of adolescents having hemoglobin level $<12 \mathrm{~g} / \mathrm{dl}$. In our results study $\mathrm{Hb}$ cut off mean $12.21 \mathrm{~g} / \mathrm{dl}$, however we have observed [24] [25]. Our finding shows that in male volunteers the mean values of $\mathrm{Hb}$ and BMI level were $12.73 \pm 1.47,19.63 \pm 1.22$ respectively. It was higher in male compared to female volunteers $11.56 \pm 0.86$, and $17.57 \pm 0.70$ respectively. In Residential area wise (Rural, Urban), in urban region the mean value of $\mathrm{Hb}=12.52 \pm 1.65$ and $\mathrm{BMI}=$ $19.04 \pm 1.33$ level was higher found as compared to Rural areas and in taluka Nawabshah the mean value of $\mathrm{Hb}=12.71 \pm 1.45$ and $\mathrm{BMI}=19.15 \pm 1.46$ was higher found as compared to Taluka Kazi Ahmed, Daur and Sakrand (Table 1).

About (56.5\%) were anemic in Rishikesh, Utterakhand, of India in school age children. The high occurrence of anemia was (36.5\%) in menarcheal girls. $90.90 \%$ anemic volunteers were belongs to lower socio-economic family. The majority common anemia was microcytic hypochromic type due to deficiency of nutrients [26]. The occurrence of anemia were higher in age group 11 - 13 years (15.5\%) and in 14 - 16 years (16.2\%) children as compare to age groups 17 - 18 year (11.4\%), for the reason that at this age the volunteers body requires balance nutrition for rapid growth (Table 2). In an urban slum in Delhi, the occurrence of anemia judged by WHO recommended "cut off" value of Haemglobin less then $11 \mathrm{~g} / \mathrm{dl}$ was found to be 76 percent amongst preschool children were documented by Gomber et al., (1998). Bentley \& Griffiths (2003) were investigated the occurrence of anemia among (4032) ever-married women aged 15 to 49 years from (3872) households in Andhra Pradesh, India. In all, 32.4 percent had mild anemia 10 $10.9 \mathrm{~g} / \mathrm{dl}$ for pregnant women, $10-11.9 \mathrm{~g} / \mathrm{dl}$ for non-pregnant women, 14.2 percent had moderate 7 - $9.9 \mathrm{~g} / \mathrm{dl}$ and 2.2 percent had severe less than $7 \mathrm{~g} / \mathrm{dl}$ anemia. The same has been supported by other investigators in both urban and rural regions. Present study also shows that in rural areas $27.8 \%$ and urban areas $15.3 \%$ volunteers were anemic observed, it was highly found in rural areas (Figure 1). The children are admitted in $\mathrm{Pa}$ kistani school at the age of 05 years. At that age, there are more load on children and need more nutrition. Age wise distribution; the occurrence of anemia was high (48\%) at age 09 - 12 years in Uttrakhand, Rishikesh, India and 15.5\% in 05 - 08 years child The resent results were in line with the past studies. The analysis conducted in school age students of Dera Ismail khan (Pakistan) (58.8\%) males were anemic with maximum at age 06 years and $(70.0 \%)$ females were anemic with maximum at age 06 years (100\%) and 10 years (66.6\%) [27]. Our findings shows that the occurrence of anemia (30.2\%) were observed in lower class income that was higher occurrence of anemia in lower class children as compared to middle class (10.6\%) and upper middle class (2.3\%) students (Table 3). Similarly findings reported by Villapando et al.. Preschool and school age children of Mexico in 1999-2006. The occurrence of anemia in 1999 was 28.1\%, $24.7 \%$ and $22.1 \%$ in lower, middle and upper class children respectively therefore occurrence of anemia was low (19.6\%) in lower class, middle class (17.2\%) and in upper class $(16.6 \%)$ in 2006 below age 5 - 11 years children. Similar findings reported by Jain 
and Jain, Anemia was more common (90.90\%) in the children belonging to the lower socio economic level and $37.5 \%$ children of upper and middle class were anemic in Rishikesh, Uttrakhand, India.

The occurrence of anemia in malnourished children was high $(66.89 \%)$ and in nourished group were (29.09) [28]. Prevalence of anemia in school age children in age groups (05 - 12 years) was high (46\%) in developed countries particularly highest rates found in Africa (49\%) and in South Asia (50\%). The anemia occurrence among school age children was 35\% in mountainous region from Northern Morocco [29]. The incidence of anemia were (14.6\%) and (15.0\%) in children of taluka Sakrand and taluka Kazi Ahmed. The occurrence was high in taluka Sakrand and taluka Kazi Ahmed respectively (Figure 1). Gender wise in males minimum $\mathrm{Hb}$ level $=10.3 \mathrm{~g} / \mathrm{dl}$, and maximum $\mathrm{Hb}=15.4 \mathrm{~g} / \mathrm{dl}$ were higher found as compared to females (Table 4 ). This study also show that in rural areas minimum $\mathrm{Hb}$ level $=9.4 \mathrm{~g} / \mathrm{dl}$, and maximum $\mathrm{Hb}=15.3$ $\mathrm{g} / \mathrm{dl}$ were lower found as compared to urban areas (Table 5), in lower income group minimum $\mathrm{Hb}$ level $=9.4 \mathrm{~g} / \mathrm{dl}$ was lowest found as compared other income groups (Table 6). In age group $12-14$ years the maximum $\mathrm{Hb}$ level $=15.4 \mathrm{~g} / \mathrm{dl}$ were higher found as compared to other age groups (Table 7), and minimum $\mathrm{Hb}$ level $=9.4 \mathrm{~g} / \mathrm{dl}$ are same in all taluka of district Shaheed Benazir Abad (Table 8). In our study Pale skin was commonly present in volunteers (Table 9). In Pakistan nutritional anemia has-been documented to be most common type of malnutrition present in children. According to the 1977 micronutrient research of Pakistan about 38\% of the population was recognized to be anemia (Micro-Nutrient Survey of Pakistan, 1977). According to Survey of National Nutrition (1988) 65\% of the Pakistani children aged 7 - 60 months were found to be anemic [8]. It also has impact on child growth, mental and psychomotor development [9]. Iron deficiency anemia in Pakistan 65 percent present in children at the age 7 to 60 years and other studies estimated different common rates i.e. 70 percent, 78 percent [10].

\section{Conclusion}

It is concluded that in present study occurrence of anemia (43.1\%) was observed, it was high in students of district Shaheed Benazirabad. The occurrence of anemia (27.8\%) was mostly present in rural areas. The occurrence of anemia (14.6\%) in taluka Sakrand and (15.0\%) in taluka Kazi Ahmed were higher as compared to taluka Nawabshah (5.5\%) and taluka Daur (8.0\%). The prevalence of anemia (30.4\%) was higher in female students as compared to (12.7\%) male students. The majority of anemic patients $(30.2 \%)$ belongs to lower income class and more anemic were observed in the age of 14 - 16 years. In the students, the incidence of anemia reduced the physiological development, immunity and reduces mental and physical activities. The anemia symptoms were difficult to diagnose, and pale skin was most common symptom of anemia in students.

\section{References}

[1] WHO (2011) Hemoglobin Concentrations for the Diagnosis of Anemia and Assessment of 
Severity. Vitamin and Mineral Nutrition Information System. World Health Organization, Geneva.

[2] Stoltzfus, R.J. (2007) Iron Deficiency: Global Prevalence and Consequences. Food Nutrition Bulletin, 24, S99-S103. https://doi.org/10.1177/15648265030244S206

[3] WHO (2008) Worldwide Prevalence of Anemia. 1993-2005 WHO Global Databases on Anemia. World Health Organization, Geneva.

[4] Al-Mekhlafi, H.M., Mahdy, M.A., Sallam, A.A., Ariffin, W.A., Al-Mekhlafi, A.M., Amran, A.A. and Surin, J. (2011) Nutritional and Socio-Economic Determinants of Cognitive Function and Educational Achievement of Aboriginal Schoolchildren in Rural Malaysia. British Journal Nutrition, 106, 1100-1106. https://doi.org/10.1017/S0007114511001449

[5] Kapil, U. and Bhavna, B. (2002) Adverse Effects of Poor Micronutrient Status during Childhood and Adolescence. Nutrition Review, 60, S84-S90.

https://doi.org/10.1301/00296640260130803

[6] Phiri, K.S., Calis, J.C.J., Faragher, B., et al. (2008) Long Term Outcome of Severe Anaemia in Malawian Children. Plos ONE, 3, 0002903. https://doi.org/10.1371/journal.pone.0002903

[7] World Health Organization Scientific Group (1977-1978) Nutritional Anaemia. WHO Tech. Rep. Series, 1968; 405, 5. Micro-Nutrient Survey of Pakistan, Nutritional Cell Islamabad Planning and Development Division, Government of Pakistan, 54-57.

[8] National Nutrition Survey (1988) Nutrition Division. National Institute of Health, Government of Pakistan, 35.

[9] World Health Organization (2001) 55th World Health Assembly. Agenda Item 13.10: Infant World Health Organization. Iron Deficiency Anaemia. Assessment, Prevention, and Control. A Guide for Programme Managers, WHO/UNICEF/UNU, Geneva.

[10] Bakhtiar, U., Khan, Y. and Nasar, R. (2007) Relationship between Maternal Related Hemoglobin and Perintal Outcome. Rawal Medical Journal, 32, 102-104.

[11] Christofides, A., Schauer, C. and Zlotkin, S.H. (2005) Iron Deficiency Anemia in among Children: Addressing a Global Public Health Problem within a Canadian Context. Paediatrics and Child Health, 10, 597-601.

[12] Looker, A.C., Dallman, P.R., Carrol, M.D., Gunter, E.W. and Johnson, C.L. (1997) Prevalence of Iron Deficiency in the United States. JAMA, 277, 973-976. https://doi.org/10.1001/jama.1997.03540360041028

[13] Dallman, P.R., Siimes, M.A. and Stekel, A. (1980) Iron Deficiency in Infancy and Childhood. American Journal Clinical Nutrition, 33, 86-118.

[14] Foy, H. and Kondi, A.A. (1953) Case of True Red Cell Aplastic Anaemia Successfully Treated with Riboflavin. Journal Pathology Bacteriology, 65, 559-564. https://doi.org/10.1002/path.1700650228

[15] Clayton, P.T. (2006) B6-Responsive Disorders: A Model of Vitamin Dependency. Journal Inheritance Metabolism Diseases, 29, 317-326. https://doi.org/10.1007/s10545-005-0243-2

[16] Thompson, R.B. (1975) A Short Textbook of Hematology. 4th Edition, Pitman Medical Publishing Company.

[17] UNICEF, UNU and WHO (2001) Iron Deficiency Anaemia. Assessment, Prevention and Control. A Guide for Programme Managers. IDA Consultation, World Health Organization.

[18] US Department of Health and Human Services (2010) Healthy People 2010: Understanding and Improving Health. 2nd Edition, Government Printing Office, Washington DC.

[19] Sutra (2005) Food and Nutrition World. Institute of Science Bangalore. 
[20] Stoltzfus, R.J. (2003) Iron Deficiency: Global Prevalence and Consequences. Food and Nutrition Bulletin, 24, S99-S103. https://doi.org/10.1177/15648265030244s206

[21] Verma, M., Chhatwal, J. and Kaur, G. (1998) Prevalence of Anemia among Urban School Children of Punjab. Indian Pediatrics, 35, 1181-1185.

[22] BBS (2003) Anaemia Prevalence Survey of Urban Bangladesh and Rural Chittagong Hill Tracts 2003. Bangladesh Bureau of Statistics, Statistics Division, Ministry of Planning, Government of the People's Republic of Bangladesh and UNICEF, Dhaka.

[23] Muthayya, S., Thankachan, P., Zimmermann, M.B., Andersson, M., Eilander, A., Miquith, D., Hurrell, R.F. and Kurpad, A.V. (2007) Low Anemia Prevalence in School-Aged Children in Bangalore, South India: Possible Effect of School Health Initiatives. European Journal of Clinical Nutrition, 61, 865-869. https://doi.org/10.1038/sj.ejcn.1602613

[24] Foo, L.H., Khor, G.L., Tee E.S. and Dhanaraj, P. (2004) Determinants of Iron Status in Malaysian Adolescents from a Rural Community. International Journal Food Science Nutrition, 55, 517-525. https://doi.org/10.1080/09637480400015786

[25] Foo, L.H., Khor, G.L., Tee, E.S. and Prabakaran, D. (2004) Iron Status and Dietary Iron Intake of Adolescents from a Rural Community in Sabah, Malaysia. Asia Pacific Journal Clinical Nutrition, 13, 48-55.

[26] Jain, N. and Jain, V.M. (2012) Prevalence of Anemia in School Children. Academic Journals, 3, 1-4.

[27] Ramzan, M., Ali, I. and Salam, A. (2009) Iron Deficiency Anemia in School Children of Dera Ismail Khan, Pakistan. Pakistan Journal of Nutrition, 8, 259-263.

https://doi.org/10.3923/pjn.2009.259.263

[28] Villapando, S., Dhamah-Levy, T., Garcia-Guerra, A., Mundo-Rosas, V., Dominguez, C. and Mejia-Rodriguez, F. (2009) The Prevalence of Anemia Decreased in Mexican Preschool and School-Age Children from 1999 to 2006. Salud Pública de México, 51, S507-S514.

[29] Zimmermann, M.B., Zeder, C., Chaouki, N., Saad, A., Torresani, T. and Hurrell, R.F. (2003) Dual Fortification of Salt with Iodine and Microencapsulated Iron: A Randomized, Double Blind, Controlled Trial in Moroccan School Children. The American Journal of Clinical Nutrition, 77, 425-432.

Submit or recommend next manuscript to SCIRP and we will provide best service for you:

Accepting pre-submission inquiries through Email, Facebook, LinkedIn, Twitter, etc. A wide selection of journals (inclusive of 9 subjects, more than 200 journals)

Providing 24-hour high-quality service

User-friendly online submission system

Fair and swift peer-review system

Efficient typesetting and proofreading procedure

Display of the result of downloads and visits, as well as the number of cited articles Maximum dissemination of your research work

Submit your manuscript at: http://papersubmission.scirp.org/

Or contact ojbd@scirp.org 